\title{
Frustrations Facing Male Nursing Students in Maternity Curriculum, Assiut University and Their Life Satisfaction.
}

\author{
Nabila Taha, Nadia Ebraheem Sayied \& Sahar Elkhishen. \\ Professor Obstetric \& Gynecological Nursing, Faculty of Nursing, Assiut University, Egypt. \\ Assistant professor Psychiatric \& Mental Health Nursing, Faculty of Nursing, Assiut University Egypt \\ Lecturer Maternal \& Neonatal Nursing Faculty of Nursing, Misr University Science \& Technology, Egypt.
}

\begin{abstract}
Background: Researches has failed to incorporate the challenges facing male nursing students. Therefore; this study Aimed at assessing the frustration facing male students in maternity curriculum and their life satisfaction. An exploratory descriptive Research Design was utilized. The Setting was Faculty of Nursing, Assiut UniversityEgypt.. Subjects was a convenient sample of all male nursing students who studied \& recently passed Maternity Curriculum; a total of 162 students were recruited. Tools for data collection included; structured interview questionnaire; Frustration scale and Life satisfaction scale. The duration for data collection lasted for 6 months precisely from January to June 2016. Results of this study revealed that, the mean age of participant students was 21.31years. There was a highly significance reversible correlation between frustration level and general feeling of satisfaction. Also high frustration level associated with low level of satisfaction. This study Concluded that, the level of frustration strongly correlated with level of satisfaction. This study Recommended depth orientation before starting maternity curriculum, workshop to discuss challenges \& consernes with male students, future researches on enrollment, frustration, satisfaction and perception of male nursing students and the importance of further researches in this field with comparison between both sexes.
\end{abstract}

Key words: Maternity curriculum, Male nursing student, Frustration \& Life satisfaction.

\section{Introduction}

In the third century B.C. in ancient India only men could have attended nursing schools and works as nurses (Devito, 2016). During middle ages, social and political changes were occurring. The health care was provided by religious orders where Christian monks and nuns provided care to sick (Ying, 2014). Women continue to be dominate nursing (Men in nursing, 2013).

Admission regulation among faculties and schools of nursing since nightingale movement of modernize nursing, males were excluded from entering career (Eswia \& EL-Sayed, 2011).For a long time, there were lack of desire and interest among students in Egypt to study nursing because of the stigma of nursing profession which may plays one of the most important obstacles for choosing nursing career (Conner, 2016). In 2011, 91\% of nurses were women and only $9 \%$ were men (Men in nursing, 2013).

Nursing is still does not benefit from men as a potential pool of candidates to improve nursing shortages (McLaughlin, 2010). Females remain the large majority of students in nursing and of nursing faculty, while males continue to represent only a very small minority in both (Mohamed \& El-Nemer, 2013).

Current days are witnessing escalating numbers of males who choosing a nursing as an occupation, even though nursing remains (as popular concept) extremely female dominated profession and not a male career (Eswia \& EL-Sayed, 2011, \& Lou et al., 2007). The involvement of males in nursing is becoming more satisfactory, one of the issues regarding male nurses is increasing support demonstrating that male nursing students face more gender based role stress and frustration than do their female peers, especially when caring for female patients (Yang et al., 2017). Clinical nurse educators are not supportive of male student nurses being in certain areas such as obstetric and paediatric nursing rotation (Cudé, 2004 \& Eswi \& El Sayed, 2011).

Studies in the United States have shown that role strain and frustration knowledgeable by male nursing students in maternity curriculum is higher than that knowledgeable by their female counterparts (Rajacich et al., $2013 \&$ Sherrod, 1991). In addition (Patterson \& Morin, 2002), interviewed eight male nursing students who had finished their maternal child rotation. They also found that participants began the maternal child clinical rotation with feelings of fear, anxiety, and the risk of rejection .

This situation also has its consequence on nursing education and training, male students were made to feel uncomfortable during their training placement; lots of male students were not allowed to contribute in the full range of caring interventions during obstetric placement workplace (Abushaikha et al., 2014).Today women have made significant progress in medicine and engineering, as a male dominant 
professions the same cannot be said of men in the nursing profession (Maykut, 2017).

\section{Significance of the study}

Male nursing students have experienced challenges in their obstetrical nursing practice because of their gender. Male nursing students face greater frustration than do female students; this may be related to the public stereotypes and Egyptian culture about male nursing students in the obstetrical setting. So, the main reason for conducting this study was to assess the frustrations facing male nursing students in maternity curriculum and their life satisfaction.

\section{Aim of the study \\ The aim of this study was to}

- Assess the frustrations facing male nursing students in maternity curriculum and their life satisfaction .

\section{Research Questions}

- Is there any frustrations facing male nursing students in maternity curriculum?

- Is there a relation between male students' frustrations and their life satisfaction?

\section{Subjects \& Methods \\ Research Design}

An exploratory descriptive design was utilized in this study.

\section{Settings}

The study was carried out in Faculty of Nursing, Assiut University, Egypt, (governmental faculty Ministry of Higher Education, and encompass multiresidential students).

\section{Subjects}

Convenient sample represents all male nursing students who studied \& recently passed Maternity Nursing Curriculum; (third \& fourth year students). A total of 162 students were recruited.

\section{Tools of data collection}

Data were collected using three tools in this study:

\section{1-Structured Interviewing Questionnaire}

Which developed by the investigators after reviewing the literatures related to the current study. It includes personal information such as student's age, residence, parents' educational level \& occupation, number and orders of brothers \& sisters, interesting in nursing education $\&$ general feeling of satisfaction.

\section{Frustration Scale}

Frustration was assessed through using a frustration scale of Mobark \& Haroon (2015), to assess frustration among graduates. Some modification were done to be suitable for students as, item number four in physical domain, items $(2,4,5)$ in specialty domain. Then revalidate the tool by a jury of five expertise from Obstetric and gynecological nursing and
Psychiatric nursing, to assess the content and validity of the tool to suit with an Egyptian culture. Cronbach's (alpha) test was done to measure the internal consistency and reliability of the tool which was (0.82). This scale consisted of 6 domains; (physical, mental, family, specialty, economic and social). Each consists of 5 statements about the sensation of frustration, an example of which is "I wish to study another field. There were three positive statements and twenty-seven negative statements, with three-point Likert scale ranging from " agree" to "disagree" Each scoring response is classified into 02 responses; (0) is assigned for agree, (1) for agree to some extent, and (2) for disagree. A high score indicated high level of frustration. The scoring system ranged from 0-40 means low frusteration,4046 moderate frusteration, and above 47 indicated severe frusteration.

\section{Life Satisfaction Scale}

Life satisfaction scale which was developed by Eldesoky (1998), which used to assess students life satisfaction, (factorial derived measure). This scale consisted of 30 statements about positive sensation of life satisfaction. For example, "I feel happy and satisfy". Items were rated on a five-point Likert scale, from strongly agree to strongly disagree. Each scoring response is classified into 1-5 degrees: 1 for never, 2 for rare, 3 for sometimes, 4 for mostly, and 5 for always. High score indicated high life satisfaction. The scoring system from 1 to79 indicated low satisfaction, ranged from 98,to112 indicated moderate satisfaction and above 112 indicated high satisfaction.

\section{Pilot Study}

A pilot study was conducted on 20 students to test feasibility of tools and time required to be applied. Simple modification was done of some items of the interviewing questionnaire that they were not consistent with this study This sample was excluded from the actual study.

\section{Administrative design}

An official permission was obtained from the research ethical committee in the faculty of nursing to approve this study Before the conduction of the pilot study as well as the actual study, an official permission was obtained from the dean of the faculty of nursing.

\section{Procedures}

The students were gathered in the faculty classes and or lab to conducting sessions for data collection according to their schedules after finishing of their study day. The students were interviewed in groups, 25 students in each session for about 30 minutes. The purpose of the study was explained by the investigators. Distributing of the tools to each student was done for filling them. The duration for data 
collection lasted for 6 months precisely from January to June, 2016.

\section{Ethical considerations}

The study protocol was approved by pertinent research and ethical committee. Informed verbal consent was taken from each student before participation in the study. No health hazards were present. Participants were assured that all their data are highly confidential, anonymity was also assured through assigned a number for each student instead of names to protect their privacy. Data were only available to the researchers and the participants.

\section{Statistical Analysis}

The data were tested for normality using the Anderson-Darling test and for homogeneity variances prior to further statistical analysis. Categorical variables were described by number and percent $(\mathrm{N}, \%)$, Chi-square test used to compare between categorical variables where continuous variables described by mean and standard deviation (Mean, SD). compare between continuous variables by t-test and ANOVA test. The Pearson correlation coefficient was used to probe the relationship between frustration and satisfaction level. Multiple linear regression analysis to assess the factors, A two-tailed $\mathrm{p}<0.05$ was considered statistically significant. All analyses were performed with the IBM SPSS 20.0 software.

\section{Results}

Table (1): Distribution of the participants by their personal data.

\begin{tabular}{|c|c|c|}
\hline Items & No. (162) & $\%$ \\
\hline $\begin{array}{l}\text { Age } \\
\text { Range } \\
\text { Mean } \pm \text { SD }\end{array}$ & \multicolumn{2}{|c|}{$\begin{array}{c}20-24 \\
21.31 \pm 0.87\end{array}$} \\
\hline $\begin{array}{l}\text { Living in } \\
\text { Family's home } \\
\text { University City } \\
\text { External housing }\end{array}$ & $\begin{array}{l}83 \\
65 \\
14\end{array}$ & $\begin{array}{c}51.2 \\
40.1 \\
8.6\end{array}$ \\
\hline $\begin{array}{l}\text { Residence } \\
\text { Rural } \\
\text { urban }\end{array}$ & $\begin{array}{l}94 \\
68\end{array}$ & $\begin{array}{l}58.0 \\
42.0\end{array}$ \\
\hline $\begin{array}{l}\text { Father's Education } \\
\text { Illiterate } \\
\text { Read and write } \\
\text { Basic education } \\
\text { Secondary } \\
\text { University }\end{array}$ & $\begin{array}{c}9 \\
13 \\
20 \\
66 \\
54\end{array}$ & $\begin{array}{c}5.6 \\
8.0 \\
12.3 \\
40.7 \\
33.3\end{array}$ \\
\hline $\begin{array}{l}\text { Father's Occupation } \\
\text { Employee } \\
\text { Free work } \\
\text { others }\end{array}$ & $\begin{array}{c}113 \\
17 \\
32 \\
\end{array}$ & $\begin{array}{l}69.8 \\
10.5 \\
19.8 \\
\end{array}$ \\
\hline $\begin{array}{l}\text { Mother's Education } \\
\text { Illiterate } \\
\text { Read and write } \\
\text { Basic education } \\
\text { Secondary } \\
\text { University }\end{array}$ & $\begin{array}{l}42 \\
11 \\
20 \\
44 \\
45\end{array}$ & $\begin{array}{c}25.9 \\
6.8 \\
12.3 \\
27.2 \\
27.8 \\
\end{array}$ \\
\hline $\begin{array}{l}\text { Mother's Occupation } \\
\text { housewife } \\
\text { Employee }\end{array}$ & $\begin{array}{c}103 \\
59 \\
\end{array}$ & $\begin{array}{l}63.6 \\
36.4 \\
\end{array}$ \\
\hline $\begin{array}{l}\text { Birth Order } \\
\text { Single } \\
\text { First } \\
\text { Second } \\
\text { Third } \\
\text { More than }\end{array}$ & $\begin{array}{c}4 \\
46 \\
41 \\
29 \\
42\end{array}$ & $\begin{array}{c}2.5 \\
28.4 \\
25.3 \\
17.9 \\
25.9\end{array}$ \\
\hline
\end{tabular}




\begin{tabular}{|l|c|c|}
\hline \multicolumn{1}{|c|}{ Items } & No. (162) & \% \\
\hline Nursing Enrollment & & 29.6 \\
Personal desire & 48 & 23.5 \\
Coordination office & 38 & 19.8 \\
Parents' desire & 32 & 24.1 \\
Occupation after graduation & 39 & 3.1 \\
Others & 5 & 69.8 \\
\hline General feeling of Satisfaction & 113 & 30.2 \\
Yes & 49 & \\
No & & \\
\hline
\end{tabular}

Table (2): Distribution of the participants by Frustration level.

\begin{tabular}{|c|c|c|c|}
\hline frustration level & No. (162) & \% & \multirow{2}{*}{ P. value } \\
\hline Low & 153 & 94.4 & \multirow{2}{*}{$<0.001 * *$} \\
\hline Moderate & 7 & 4.3 & \\
\hline High & 2 & 1.2 & \\
\hline
\end{tabular}

Table (3): Distribution of the participants by level of life satisfaction.

\begin{tabular}{|c|c|c|c|}
\hline satisfaction Level & No. (162) & \% & P. value \\
\hline Low & 36 & 22.2 & \multirow{2}{*}{0.103} \\
\hline Moderate & 61 & 37.7 & \\
\hline High & 65 & 40.1 & \\
\hline
\end{tabular}

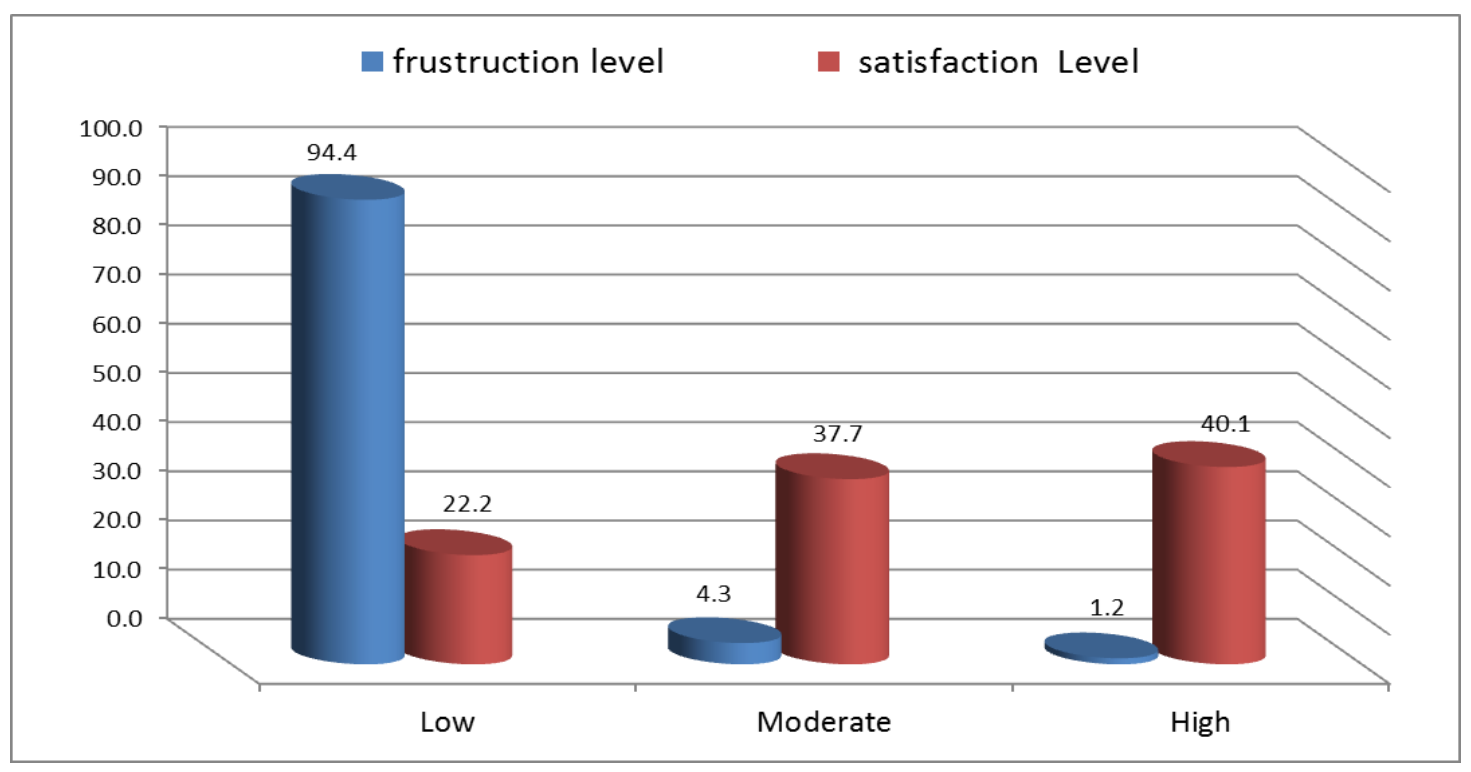

Figure (1): Distribution of the participant by their Frustration and satisfaction Level. 
Table (4): Relationship between frustration level and personal data (no. 162).

\begin{tabular}{|c|c|c|c|c|c|c|c|}
\hline \multirow{4}{*}{ 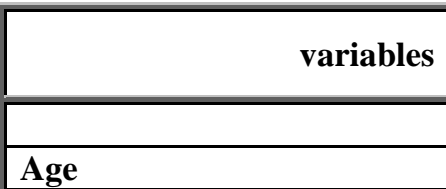 } & \multicolumn{6}{|c|}{ frustration } & \multirow{3}{*}{ P. value } \\
\hline & \multicolumn{2}{|c|}{ Low } & \multicolumn{2}{|c|}{ Moderate } & \multicolumn{2}{|c|}{ High } & \\
\hline & No. & $\%$ & No. & $\%$ & No. & $\%$ & \\
\hline & \multicolumn{2}{|c|}{$21.28 \pm 0.88$} & \multicolumn{2}{|c|}{$21.33 \pm 0.78$} & \multicolumn{2}{|c|}{$22 \pm 1.00$} & 0.190 \\
\hline \multicolumn{8}{|l|}{ Living in } \\
\hline Family's home & 68 & 52.3 & 11 & 40.7 & 4 & 80.0 & \multirow{3}{*}{0.556} \\
\hline City University & 51 & 39.2 & 13 & 48.1 & 1 & 20.0 & \\
\hline External housing & 11 & 8.5 & 3 & 11.1 & 0 & 0.0 & \\
\hline \multicolumn{8}{|l|}{ Residence } \\
\hline Rural & 75 & 57.7 & 15 & 55.6 & 4 & 80.0 & \multirow{2}{*}{0.587} \\
\hline urban & 55 & 42.3 & 12 & 44.4 & 1 & 20.0 & \\
\hline \multicolumn{8}{|l|}{ Father's Education } \\
\hline Illiterate & 7 & 5.4 & 2 & 7.4 & 0 & 0.0 & \multirow{5}{*}{0.896} \\
\hline Read and write & 12 & 9.2 & 1 & 3.7 & 0 & 0.0 & \\
\hline Basic education & 17 & 13.1 & 2 & 7.4 & 1 & 20.0 & \\
\hline Secondary & 51 & 39.2 & 12 & 44.4 & 3 & 60.0 & \\
\hline University & 43 & 33.1 & 10 & 37.0 & 1 & 20.0 & \\
\hline \multicolumn{8}{|l|}{ Father's Occupation } \\
\hline Employee & 95 & 73.1 & 15 & 55.6 & 3 & 60.0 & \multirow{3}{*}{0.437} \\
\hline handicraftsman & 12 & 9.2 & 4 & 14.8 & 1 & 20.0 & \\
\hline others & 23 & 17.7 & 8 & 29.6 & 1 & 20.0 & \\
\hline \multicolumn{8}{|l|}{ Mother's Education } \\
\hline Illiterate & 37 & 28.5 & 4 & 14.8 & 1 & 20.0 & \multirow{5}{*}{0.308} \\
\hline Read and write & 9 & 6.9 & 2 & 7.4 & 0 & 0.0 & \\
\hline Basic education & 16 & 12.3 & 2 & 7.4 & 2 & 40.0 & \\
\hline Secondary & 31 & 23.8 & 12 & 44.4 & 1 & 20.0 & \\
\hline University & 37 & 28.5 & 7 & 25.9 & 1 & 20.0 & \\
\hline \multicolumn{8}{|l|}{ Mother's Occupation } \\
\hline housewife & 82 & 63.1 & 17 & 63.0 & 4 & 80.0 & \multirow{2}{*}{0.741} \\
\hline Employee & 48 & 36.9 & 10 & 37.0 & 1 & 20.0 & \\
\hline \multicolumn{8}{|l|}{ Birth Order } \\
\hline single & 4 & 3.1 & 0 & 0.0 & 0 & 0.0 & \multirow{5}{*}{0.064} \\
\hline First & 35 & 26.9 & 9 & 33.3 & 2 & 40.0 & \\
\hline Second & 36 & 27.7 & 4 & 14.8 & 1 & 20.0 & \\
\hline Third & 17 & 13.1 & 10 & 37.0 & 2 & 40.0 & \\
\hline More this & 38 & 29.2 & 4 & 14.8 & 0 & 0.0 & \\
\hline Nursing Enrollment & & & & & & & \\
\hline Personal desire & 43 & 33.1 & 5 & 18.5 & 0 & 0.0 & \\
\hline Coordination office & 28 & 21.5 & 9 & 33.3 & 1 & 20.0 & \\
\hline Parents' desire of & 27 & 20.8 & 3 & 11.1 & 2 & 40.0 & 0.374 \\
\hline Occupation after graduation & 28 & 21.5 & 9 & 33.3 & 2 & 40.0 & \\
\hline others & 4 & 3.1 & 1 & 3.7 & 0 & 0.0 & \\
\hline General feeling of Satisfactio & & & & & & & \\
\hline Yes & 100 & 76.9 & 12 & 44.4 & 1 & 20.0 & \\
\hline No & 30 & 23.1 & 15 & 55.6 & 4 & 80.0 & 0.000 \\
\hline
\end{tabular}

1- Chi-squire test. ** Highly statistically significant difference $(p<0.01)$.

2- One-way ANOVA 
Table (5): Relationship between satisfaction level and personal data (no.162).

\begin{tabular}{|c|c|c|c|c|c|c|c|}
\hline \multirow{3}{*}{ variables } & \multicolumn{6}{|c|}{ satisfaction } & \multirow{3}{*}{ P. value } \\
\hline & \multicolumn{2}{|c|}{ Low } & \multicolumn{2}{|c|}{ Moderate } & \multicolumn{2}{|c|}{ high } & \\
\hline & No. & $\%$ & No. & $\%$ & No. & $\%$ & \\
\hline Age & \multicolumn{2}{|c|}{$21.44 \pm 0.96$} & \multicolumn{2}{|c|}{$21.27 \pm \mathbf{0 . 8 4}$} & \multicolumn{2}{|c|}{$21.34 \pm \mathbf{0 . 9 0}$} & 0.734 \\
\hline \multicolumn{8}{|l|}{ Living in } \\
\hline Family's home & 7 & 43.8 & 46 & 51.1 & 30 & 53.6 & \multirow{3}{*}{0.206} \\
\hline City University & 6 & 37.5 & 40 & 44.4 & 19 & 33.9 & \\
\hline External housing & 3 & 18.8 & 4 & 4.4 & 7 & 12.5 & \\
\hline \multicolumn{8}{|l|}{ Residence } \\
\hline Rural & 9 & 56.3 & 56 & 62.2 & 29 & 51.8 & \multirow{2}{*}{0.457} \\
\hline urban & 7 & 43.8 & 34 & 37.8 & 27 & 48.2 & \\
\hline \multicolumn{8}{|l|}{ Father's Education } \\
\hline Illiterate & 0 & 0.0 & 7 & 7.8 & 2 & 3.6 & \multirow{5}{*}{0.447} \\
\hline Read and write & 2 & 12.5 & 8 & 8.9 & 3 & 5.4 & \\
\hline Basic education & 2 & 12.5 & 7 & 7.8 & 11 & 19.6 & \\
\hline Secondary & 8 & 50.0 & 37 & 41.1 & 21 & 37.5 & \\
\hline University & 4 & 25.0 & 31 & 34.4 & 19 & 33.9 & \\
\hline \multicolumn{8}{|l|}{ Father's Occupation } \\
\hline Employee & 14 & 87.5 & 58 & 64.4 & 41 & 73.2 & \multirow{3}{*}{0.360} \\
\hline handicraftsman & 1 & 6.3 & 10 & 11.1 & 6 & 10.7 & \\
\hline Others & 1 & 6.3 & 22 & 24.4 & 9 & 16.1 & \\
\hline \multicolumn{8}{|l|}{ Mother's Education } \\
\hline Illiterate & 4 & 25.0 & 23 & 25.6 & 15 & 26.8 & \multirow{5}{*}{0.690} \\
\hline Read and write & 0 & 0.0 & 8 & 8.9 & 3 & 5.4 & \\
\hline Basic education & 1 & 6.3 & 10 & 11.1 & 9 & 16.1 & \\
\hline Secondary & 7 & 43.8 & 25 & 27.8 & 12 & 21.4 & \\
\hline University & 4 & 25.0 & 24 & 26.7 & 17 & 30.4 & \\
\hline \multicolumn{8}{|l|}{ Mother's Occupation } \\
\hline housewife & 9 & 56.3 & 57 & 63.3 & 37 & 66.1 & \multirow{2}{*}{0.770} \\
\hline Employee & 7 & 43.8 & 33 & 36.7 & 19 & 33.9 & \\
\hline \multicolumn{8}{|l|}{ Birth Order } \\
\hline single & 0 & 0.0 & 2 & 2.2 & 2 & 3.6 & \multirow{5}{*}{0.350} \\
\hline First & 4 & 25.0 & 25 & 27.8 & 17 & 30.4 & \\
\hline Second & 5 & 31.3 & 18 & 20.0 & 18 & 32.1 & \\
\hline Third & 3 & 18.8 & 22 & 24.4 & 4 & 7.1 & \\
\hline More this & 4 & 25.0 & 23 & 25.6 & 15 & 26.8 & \\
\hline Nursing Enrollment & & & & & & & \\
\hline Personal desire & 2 & 12.5 & 26 & 28.9 & 20 & 35.7 & \\
\hline coordination office & 3 & 18.8 & 26 & 28.9 & 9 & 16.1 & \\
\hline Parents' desire & 3 & 18.8 & 18 & 20.0 & 11 & 19.6 & 0.151 \\
\hline Occupation after graduation & 6 & 37.5 & 18 & 20.0 & 15 & 26.8 & \\
\hline others & 2 & 12.5 & 2 & 2.2 & 1 & 1.8 & \\
\hline General feeling of Satisfaction & & & & & & & \\
\hline Yes & 7 & 43.8 & 55 & 61.1 & 51 & 91.1 & $0000 * *$ \\
\hline No & 9 & 56.3 & 35 & 38.9 & 5 & 8.9 & $0.000^{* *}$ \\
\hline
\end{tabular}

1- Chi-squire test. ** Highly statistically significant difference $(p<0.01)$.

2- One-way ANOVA 


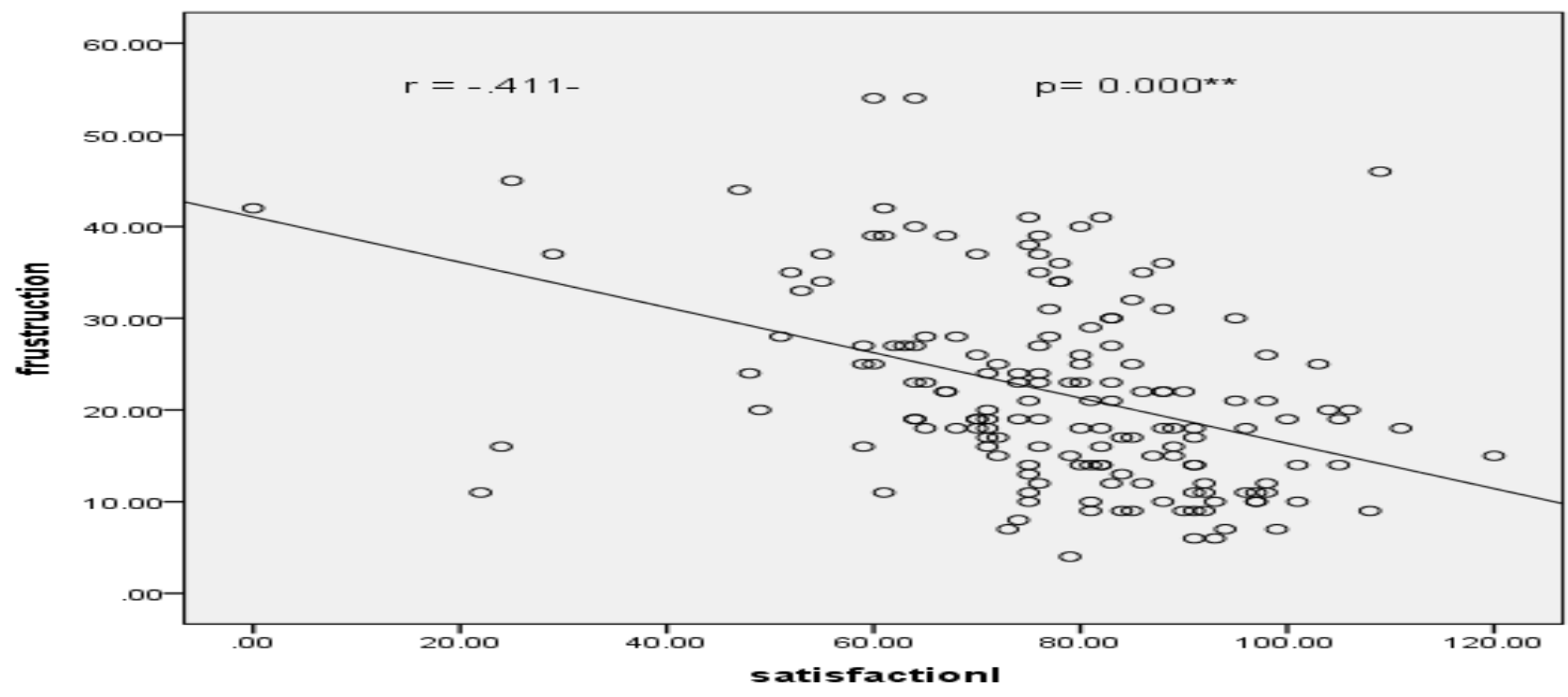

Figure (2): Relation between level of satisfaction and frusteration.

** Highly significant reversible correlation $(p<0.01)$

* Statistically significant correlation $(p<0.05)$

Table (6): Multiple linear regression analysis to assess the factors affects in frustration and satisfaction (no. 162)

\begin{tabular}{|l|c|c|c|c|c|c|}
\hline \multirow{2}{*}{ Factors } & \multicolumn{3}{|c|}{ frustration } & \multicolumn{3}{c|}{ satisfaction } \\
\cline { 2 - 7 } & Beta & $\mathrm{t}$ & $\mathrm{Sig}$. & Beta & $\mathrm{t}$ & Sig. \\
\hline age & 0.010 & 0.128 & 0.898 & 0.045 & 0.600 & 0.549 \\
\hline Living & 0.011 & 0.151 & 0.880 & -0.089 & -1.209 & 0.229 \\
\hline Residence & -0.112 & -1.443 & 0.151 & 0.126 & 1.607 & 0.110 \\
\hline Father's education & 0.039 & 0.378 & 0.706 & 0.110 & 1.061 & 0.290 \\
\hline Father's occupation & 0.197 & 2.518 & $0.013^{*}$ & 0.009 & 0.108 & 0.914 \\
\hline Mother's education & 0.062 & 0.524 & 0.601 & -0.184 & -1.542 & 0.125 \\
\hline Mother's occupation & 0.019 & 0.212 & 0.832 & 0.058 & 0.626 & 0.533 \\
\hline Birth order & -0.015 & -0.193 & 0.847 & -0.082 & -1.056 & 0.293 \\
\hline Nursing Enrollment & 0.082 & 1.112 & 0.268 & -0.071 & -0.947 & 0.345 \\
\hline $\begin{array}{l}\text { General feeling } \\
\text { of satisfaction }\end{array}$ & 0.409 & 5.502 & $0.000^{* *}$ & -0.410 & -5.454 & $0.000^{* *}$ \\
\hline
\end{tabular}

* Statistically significant difference $(p<0.05)$

** Highly Statistically significant difference $(p<0.01)$

Table (1): Shows that, the mean age of participant students was 21.31 years, more than half of them were from rural areas and living in family's home. More than two thirds of participant students' fathers were employees, and their mothers were housewives. Nearly one third of participant students' parents had university education. Nearly one third of prticipant students were enrolled in nursing based on personal desire, and more than two thirds of them had a general feeling of satisfaction.

Table (2): Shows that the majority of participant students had a low level of frustration.

Table (3) Reveals that, nearly half of participant students had a high level of satisfaction.
Figure (1\&2): Illusterat high level of satisfaction associated with low level of frustration.

Table (4): Shows a highly statistically significant differences between level of frustration and general feeling of satisfaction.

Table (5): Clarifies a highly statistically significant differences between level of satisfaction ( by using standardized scale) and general feeling of satisfaction; (by using one open ended question in an interview questionnaire).

Table (6): Demonstrates that, the general feeling of satisfaction was a factor affected on level of frustration and level of satisfaction with a statistically significant differences. 


\section{Discussion}

Despite the constant changes that impact health care, the sex imbalance of the nursing education remains constant (Keogh \& Lynn, 2007).It is evident that although nursing has traditionally been a femaledominated profession, there have been a small number of males entering the profession, (Meadus \& Twomey, 2011).

The present study indicated that, nearly one third of prticipant students were enrolled in nursing based on personal desire, while nearly one quarter enrolled in nursing for occupation after graduation. More than two thirds of them had a general feeling of satisfaction. These findings similar to some extend the results of Hyun \& Yi, (2016) who studied the predictors of subjectives happiness for male nursing students in Korea. They found that, more than one third of participants enrolled in nursing for getting a job easily, while more than three quarters of participants were satisfied. Also this disagreed with Feng et al., (2016) who studied a chinese male nursing students, they found that, male students who were in an advanced diploma nursing program reported greater satisfaction than did those in a bachelor's nursing program and those for whom nursing was not the first-choice major. Also Young, (2014) studied the relationship of career identity, major satisfaction and college adaptation of nursing freshmen, he found that, nearly half of the students were satisfied. These findings were inagreement with Keogh \& Lynn, (2007), who reported that, there were lack of desire and enthusiasm among male students in Egypt to study nursing because of the stigma of nursing profession which may play one of the major obstacles for choosing nursing career.

The current study results revealed that, the majority of participant students had a low level of frustration with high level of life satisfaction. This may be attributed to appointment after graduation and getting a job. In the same respect, Kim \& Kim, (2012), found that, the negative emotion of college nursing students was greater than other college students due to the fact that nursing students were burdened with the responsibilities of future health care professional . Also Cha \& Seo, (2012), revealed that, moreover, college students experience anger due to psychological stressors, which were related to low self- esteem, unstable family, or faculty environment. In addition Chun et al., (2016), invested the subjective well-being and influential factors of undergraduate male nursing students in department of nursing,Bengbu Medical College, China. They found that, the undergraduate male nursing students experienced higher life satisfaction.
The present study found that, the general feeling of satisfaction was a factor affected in level of frustration and level of life satisfaction with a statistically significant difference. The possible explanation of this finding was explained by Bernard Hodes Group, (2005) \& Rajacich et al., (2013), who reported that, men in nursing also had positive experiences that enabled them to remain in the profession. They cited deriving personal rewards from making a difference in their clients' lives. Being a minority in the female dominated profession positively enhanced the men's visibility as representatives for the wider male gender to join nursing . Also Feng et al., (2016) stated that, male nurses are professionals who care by the same way as female, however stereotyping them does exist exposing male nurses to homophobia in the workplace.

While, Reeve (2012), \& Toylor \& Royes (2012) stated that, nursing students experience various tensions as well as anger and negative self - esteem from their clinical learning environment. In this context, Rajacich et al., (2013) found that. male nurses also experienced various challenges from the female colleagues which leading to a high level of dissatisfaction among male nurses. Finallly the high level of students' life satisfactin and low level of frustration may be attributed to; students' satisfaction with God's will, or to meet the desire of their parents or may be due to the appointment after graduation. While some other students loved working in any field related to medicine.

\section{Conclusion}

According to the findings of the present study, it can be concluded that, a low level of frustration was associated with high level of life satisfaction. There was a reversible correlation between them.

\section{Recommendations}

- Future researches on enrollment, frustration, satisfaction and perception of male nursing students would be useful in profession.

- Further researches in this field with comparison between both sexes.

\section{Limitation of the study}

This study was limited by the small number of male participants enrolled in maternity curriculum. Additionally, the lack of comparison of the experiences of the female enrolled in the same curriculum was also an evident limitation and resulted in some speculation. A comparison to the both sexes of students enrolled in the same curriculum would be useful. 


\section{Acknowledgement}

We would like to acknowledge the male nursing students of the faculty of nursing, Assiut University for their valuable participation \& cooperation.

\section{References}

1. Abushaikha L., Mahadeen A., Abdelkader R., (2014): Academic challenges and positive aspects: Perceptions of male nursing students. Int Nurs Rev. 61(2): 263-269. http://dx.doi.org/10.11 11/inr.12098.

2. Bernard Hodes Group (2005): Men in nursing study. Retrieved from www.aamn.org/docs/meninnursing2005survey.p df >. Accessed in Nov 2015.

3. Cha N., \& Seo E., (2012): The relationship between anger expression and self- esteem in nursing college students. Journal of Korean Academy Community Health Nursing. 23: 451459.

4. Chun W., Xue S., \& Fanf W., (2016): An investigation of subjective well-being and influential factors of undergraduate male nursing student. Chinese Journal of General Practice-06 http://en.cnki.com.cn/Journal_en/E-E000SYQY-2016-06.htm

5. Conner B., Anderson B., Matutina R., (2016): Exploring the perceptions of male nursing students enrolled in an accelerated baccalaureate degree nursing program Medical University of South Carolina, United States. Journal of Nursing Education and Practice, Vol. 6, No. 8, p 38.

6. Cudé, G., (2004): Do men have a role in maternal-newborn nursing? WHONN Lifelines, 8(4), 342-347.

7. Devito J., (2016): The experience of male nursing students. View issue TOC., Volume 51, Issue 4. Pp 246-253.

8. Eswi, A., \& El Sayed, Y., (2011): 'The experience of Egyptian male student nurses during attending maternity nursing clinical course', Nurse Education in Practice 11(2), 93 98.

9. Feng D., Zhao W., Shen S., Chen J., \& Li L., (2016): The influence of perceived prejudice on willingness to be a nurse via the mediating effect of satisfaction with major: A crosssectional study among chinese male nursing students. Nures Education Today, Volume 42,Pages 69-72.

10. Hyun P., \& Yi J., (2016): Predictors of subjectives happiness for male nursing students. Journal of the Korean Data and
Information Science Society, Volume 27, Issue 2, pp.511-522.

11. Kim G.,\& Kim K., (2012): Factors related to happiness in first year women nursing students. Journal of Korean Academy Psychiatric Mental Health Nursing. 21:149-157.

12. Lou, J., Yu, H., Hsu, H., \& Dai, H., (2007): Astudy of role stress, organizational commitment and intention to quit among male nurses in southern Taiwan. The Journal of Nursing Research, 15(1), 43Y53.

13. Maykut C., Lee A., Argueta N., Grant S., \& Miller C., (2017): conscious engagement in undergraduate male nursing students: facilitating voice through an action research project. Canada Journal of action research, vol. 17, no. 2.

14. McLaughlin K., Muldoon O., Moutray M., (2010): Gender, Gender Roles and Completion of Nursing Education: A longitudinal study. Nurse Education Today. 30(4): 303-7. PMid:19758730 http://dx.d oi.org/10.1016/j.nedt.2009.08.005

15. Meadus, R., \& Twomey, J., (2011): 'Men student nurses: The nursing education experience', Nursing Forum 46(4), 269-279.

16. Men in Nursing, (2013): Occupations American Community Survey Highlight Report., February. Retrieved from https://www.census.gov/people/io/files/Men_in _Nursing_Occ upations.pdf.

17. Mobark \& Haroon (2015): Thesis, Frustration Among The Unemployed University Graduates, Sudan University of Science and Technology, College of Graduate Studies,Faculty of Education.

18. Mohamed H., \& El- Nemer A., (2013): The Experience of Newly Enrolled Egyptian Male Nursing Students into Maternity Nursing Curriculum,

19. Life Science Journal;10 (1) 2810-2815. http://www.lifesciencesite.com

20. Patterson, B., \& Morin, K., (2002): Perceptions of the maternalYchild clinical rotation: The male student nurse experience. Journal of Nursing Education, 41(6), 266Y272.

21. Rajacich, D., Kane, D., Williston, C., \& Cameron, S., (2013): If they do call you a nurse, it is always a "male nurse": Experiences of men in the nursing profession. Nursing Forum, 48(1), 71-80.

22. Reeve K., (2012): Perceived stress and social support in undergraduate nursing students' educational experiences. Nurse Education Today. 33:419-929. 
23. Sherrod, R., (1991): Obstetrical role strain for male nursing students. Western Journal of Nursing Research, 13(4), 494Y502.

24. Toylor H., \& Royes H., (2012): Self efficacy and resilience in baccalaureate nursing students. International Journal of Nursing Education Scholarship,9:1-13.

25. Yang C., Yu H., Chin Y., Lee L., (2017): There is nothing wrong with being a nurse: The experiences of male nursing students in Taiwan. Japan Journal of Nursing Science, Volume 14, Issue 4, Pp 332-340.

26. Ying C., (2014): An ethnographical study on the academic experiences of Chinese male nursing students. Nurse Education in Practice Volume 14, Issue 2, Pages 130-136.

27. Young C., (2014): The Relationship of Career Identity, Major Satisfaction and College Adaptation of Nursing Freshmen. Journal of the Korea Academia-Industrial cooperation Society,Volume 15, Issue 5, pp.2937-2945.

المراجع العربية

28. الأسوقي، مجدي(1998) : مقياس الرضا عن الحياة كراسة

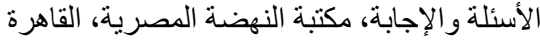

